\section{POTENTIAL LEAVES OF TREMBESI (Albizia saman (Jacq.) Merr.) AS BIOACCUMULATORS FOR HEAVY METAL (PB) IN MANADO CITY}

\section{Potensi Daun Trembesi (Albizia saman (Jacq.) Merr.) Sebagai Bioakumulator Logam Berat Timbal (Pb) Di Kota Manado}

\author{
Albertin Indriani 1), \\ Bobby J.V. Polii ${ }^{2)}$, \\ Tommy Ogie ${ }^{2)}$
}

1) Program Studi Agroteknologi, Fakultas Pertanian, Universitas Sam Ratulangi, Manado, 95115, Indonesia

2) Dosen Program Studi Agroteknologi, Fakultas Pertanian, Universitas Sam Ratulangi, Manado, 95115, Indonesia

*Corresponding author: albertinindriani17@gmail.com

\section{Abstract}

This research is a survey study that aims to determine the lead $(\mathrm{Pb})$ content in the leaves of trembesi (Albizia saman (Jacq.) Merr.) in Taman Kesatuan Bangsa, Jalan Boulevard and Tugu Boboca, and to see the relationship between traffic density and lead $(\mathrm{Pb})$ content. on the leaves of trembesi (Albizia saman (Jacq.) Merr.) in the National Unity Park, Jalan Boulevard and Tugu Boboca. The results showed that the heavy metal content of lead $(\mathrm{Pb})$ in Manado City, in several places such as Taman Kesatuan Bangsa, Jalan Boulevard and around Tugu Bobocca ranged from 0.59 to $0.84 \mathrm{Ppm}$. Based on the quality standard of $\mathrm{Pb}$ in the air according to PP No. 41 of 1999 of $2 \mathrm{~g} / \mathrm{Nm} 3$ $\mathrm{Pb}$ content in the city of Manado is still below the threshold for $\mathrm{Pb}$ quality standards in the air. However, when compared with environmental quality standards for $\mathrm{Pb}$ parameters in the air according to $\mathrm{WHO}$, the maximum permissible limit is $0.5 \mathrm{~g} / \mathrm{Nm} 3$. Pb content has exceeded the threshold for $\mathrm{Pb}$ contamination in the air according to WHO standards. The relationship between traffic density and lead $(\mathrm{Pb})$ content in trembesi leaves shows that there is a relationship between the number of motorized vehicles and the $\mathrm{Pb}$ content in trembesi leaves, but the relationship between the number of motorized vehicles and the $\mathrm{Pb}$ content is moderate. The high and low $\mathrm{Pb}$ content in the leaves is not only influenced by the large number of vehicles that pass on the road, but there are other factors, namely wind direction and speed, and the distance of the tree from the pollutant source.

Keywords: Trembesi leaf; Lead (Pb); Motor vehicle.

\begin{abstract}
Abstrak
Penelitian ini merupakan penelitian survei yang bertujuan Untuk mengetahui kandungan timbal $(\mathrm{Pb})$ pada daun trembesi (Albizia saman (Jacq.) Merr.) di Taman Kesatuan Bangsa, Jalan Boulevard dan Tugu Boboca, serta melihat hubungan kepadatan lalu lintas dengan kandungan timbal $(\mathrm{Pb})$ pada daun trembesi (Albizia saman (Jacq.) Merr.) di Taman Kesatuan Bangsa, Jalan Boulevard dan Tugu Boboca. Hasil penelitian menunjukkan bahwa Kandungan logam berat timbal $(\mathrm{Pb})$ yang ada di Kota Manado, dibeberapa tempat seperti di Taman Kesatuan Bangsa, Jalan Boulevard dan sekitar Tugu Bobocca berkisar antara 0,59-0,84 Ppm. Berdasarkan baku mutu $\mathrm{Pb}$ di udara menurut PP No. 41 Tahun 1999 sebesar $2 \mu \mathrm{g} / \mathrm{Nm} 3$ Kandungan Pb di kota Manado masih dibawah ambang batas baku mutu $\mathrm{Pb}$ di udara. Namun jika dibandingkan dengan baku mutu lingkungan untuk parameter $\mathrm{Pb}$ di udara menurut WHO, dengan batas syarat maksimal yang diperbolehkan adalah sebesar $0,5 \mu \mathrm{g} / \mathrm{Nm} 3$ Kandungan $\mathrm{Pb}$ telah melebihi ambang batas cemaran Pb di udara menurut standar WHO. Hubungan kepadatan lalu lintas dengan kandungan timbal $(\mathrm{Pb})$ pada daun trembesi menunjukkan bahwa adanya hubungan antara jumlah kendaraan bermotor dengan kandungan $\mathrm{Pb}$ pada daun trembesi , akan tetapi hubungan yang terjadi antara jumlah kendaraan bermotor dengan kandungan $\mathrm{Pb}$ ini lemah. Tinggi rendahnya kandungan $\mathrm{Pb}$ pada daun tidak hanya di pengaruhi oleh banyaknya jumlah kendaraan yang melintas dijalan, tetapi ada faktor lain yaitu arah dan kecepatan angin, serta jarak pohon dengan sumber pencemar.
\end{abstract}

Kata Kunci : Daun trembesi; Timbal $(\mathrm{Pb})$; Kendaraan bermotor. 


\section{PENDAHULUAN}

Tingginya jumlah kendaraan bermotor menyebabkan peningkatan pencemaran udara melalui emisi yang dihasilkan. Selain gas, polutan yang perlu diwaspadai dari sumber kendaraan bermotor adalah timbal atau timah hitam (Witchayo, 2014).

Berdasarkan pemantauan dari pencemaran udara di perkotaan, emisi transportasi terbukti sebagai penyumbang pencemaran udara tertinggi di Indonesia, yakni sekitar 85 persen. Hal ini diakibatkan oleh laju pertumbuhan kepemilikan kendaraan bermotor yang tinggi. Sebagian besar kendaraan bermotor menghasilkan emisi gas buang yang buruk, baik akibat perawatan yang kurang memadai maupun penggunaan bahan bakarnya.

Data Badan Pusat Statistik (BPS) Kota Manado 2019 jumlah penduduk Kota Manado Tahun 2018 sebesar 431.880 jiwa meningkat 1.7147 jiwa $(0,41 \%)$ dari tahun 1997. Banyaknya kendaraan di Kota Manado berjumlah 261.775 kendaraan yang terdiri dari sedan 3.299, jeep 5.026, minibus 5 , bus 3.538 , microbus 578 , bus light truck 5.752, truk 1.139, sepeda motor 174.451, dan roda 3 berjumlah 815 unit.

Berdasarkan data dari Dinas Perhubungan 2019 pertumbuhan kendaraan tiap tahun rata-rata meningkat $10 \%$. Menurut Muldiyanto et al. (2007) menyatakan, tingginya tingkat kepadatan lalu lintas mengurangi ruang gerak kendaraan, kondisi ini berpotensi menyebabkan kemacetan yang berdampak secara langsung terhadap peningkatan pencemaran udara. Timbal $(\mathrm{Pb})$ merupakan salah satu logam berat yang mencemari udara, dihasilkan dari emisi gas buang kendaraan bermotor yang menggunakan bahan bakar bensin bertimbal. Bensin mengandung senyawa timbal dalam bentuk tetra ethyl lead (TEL) berkisar 0,3 gr/L $0,45 \mathrm{gr} / \mathrm{L}$. Alkyl-Pb yang terdapat dalam bahan bakar ini juga mudah menguap dan larut dalam lemak sehingga mudah diabsorbsi oleh manusia melalui inhalasi, ingesti ataupun dermal (Palar, 2004).

Pencemaran dari bahan bakar bensin bertimbal semakin tinggi seiring dengan bertambahnya kendaraan bermotor, sehingga manusia dan lingkungan di sekitarnya akan lebih mudah terpapar dengan bahan berbahaya ini.

Timbal $(\mathrm{Pb})$ yang berasal dari emisi kendaraan bermotor akan mencemari udara, tanaman, hewan, dan manusia dengan berbagai cara seperti sedimentasi, presipitasi dan inhalasi (Palar, 2004).

Menurut Environment Project Agency, sekitar 25\% logam berat Timbal $(\mathrm{Pb})$ tetap berada dalam mesin dan $75 \%$ lainnya akan mencemari udara. Emisi timbal $(\mathrm{Pb})$ dari gas buang kendaraan bermotor akan menimbulkan pencemaran udara dimanapun kendaraan itu berada. Salah satu cara pemantauan pencemaran timbal $(\mathrm{Pb})$ adalah dengan menggunakan tanaman sebagai bioindikator.

Setiap tanaman memiliki kemampuan yang berbeda-beda dalam menyesuaikan diri terhadap penyerapan logam berat di udara sehingga menyebabkan adanya tingkat kepekaan, yaitu sangat peka, peka, dan kurang peka. Tingkat kepekaan tumbuhan ini berhubungan dengan kemampuan tumbuhan untuk menyerap dan mengakumulasikan logam berat yang ada.

Sehingga beberapa tanaman tertentu dapat menjadi bioindikator dalam menyerap logam berat di udara. Organ tanaman yang baik sebagai bioindikator yang paling peka terhadap pencemaran yaitu organ daun (Fardiaz,1992).

Tanaman trembesi (Albizia saman (Jacq.) Merr.) merupakan salah satu pohon peneduh jalan yang banyak dijumpai di kota Manado. Selain sebagai tanaman peneduh, tanaman ini juga di gunakan sebagai tanaman penghijau dan tanaman penyejuk jalan yang banyak di temui di 
kota Manado dibanding dengan jenis tanaman peneduh lainnya.

Menurut Karimuddin (2016), karena bentuk kanopinya indah dan luas, trembesi (Albizia saman (Jacq.) Merr) cocok dipergunakan sebagai tanaman pelindung di pinggir jalan besar, bandara atau tamantaman kota, sekaligus penyerap polutan seperti logam berat timbal dan karbon.

Trembesi (Albizia saman (Jacq.) Merr) digunakan terutama sebagai pohon peneduh dan hiasan. Trembesi (Albizia saman) memiliki daya serap gas $\mathrm{CO} 2$ yang sangat tinggi. Satu batang trembesi mampu menyerap 28,5 ton gas $\mathrm{CO} 2$ setiap tahunnya dan juga mampu menurunkan konsentrasi gas secara efektif sebagai tanaman penghijauan dan memiliki kemampuan menyerap air tanah yang kuat.

Daun trembesi juga dapat menyerap $\mathrm{Pb}$ yang cukup tinggi dikarenakan bentuk daun trembesi yang memiliki bulu halus pada permukaan daun serta dapat menyerap CO2 (Suhaemi et al., 2014). Daun trembesi (Albizia saman (Jacq.) Merr.) sebagai Bioakumulator dalam menyerap logam berat timbal $(\mathrm{Pb})$ dapat menjadi solusi dalam mengurangi pencemaran udara, dengan demikian tanaman pertanian yang ada di perkotaan dapat terhindar dari logam berat timbal $(\mathrm{Pb})$ yang di sebabkan oleh emisi kendaraan bermotor .

Adapun tujuan dari penelitian ini, Untuk mengetahui kandungan timbal $(\mathrm{Pb})$ pada daun trembesi (Albizia saman (Jacq.) Merr.) di Taman Kesatuan Bangsa, Jalan Boulevard dan Tugu Boboca, serta melihat hubungan kepadatan lalu lintas dengan kandungan timbal $(\mathrm{Pb})$ pada daun trembesi (Albizia saman (Jacq.) Merr.) di Taman Kesatuan Bangsa, Jalan Boulevard dan Tugu Boboca.

\section{METODOLOGI PENELITIAN}

Waktu dan Tempat Penelitian
Penelitian ini dilaksanakan selama 2 bulan, dari bulan April sampai dengan bulan Mei 2021. Lokasi pengamatan dan pengambilan sampel dilakukan pada 3 lokasi berbeda ( di pusat kota, tengah, dan pinggir kota) yakni di Taman Kesatuan Bangsa, Jalan Boulevard dan Tugu Boboca. Kemudian sampel dianalisis di Laboratorium Balai Riset dan Standardisasi Industri Manado (BARISTAND).

Alat dan Bahan

Alat-alat yang digunakan pada penelitian ini adalah gunting tanaman, timbangan analitik, tabung reaksi, labu ukur, kertas saring biasa, mikropipet, plastik transparan, pisau, botol coklat, tanur, kurs porselin (Crucible), gegep (penjepit), hot plate, penggilingan, stopwatch, oven, Spektrofotometer Serapan Atom (SSA), hantally counter, alat tulis dan label.

Sedangkan bahan yang akan digunakan dalam penelitian ini adalah daun Pohon Trembesi (Albizia saman (Jacq.) Merr.), HNO3 pekat, aquades, aluminium foil, larutan induk $\mathrm{Pb}(\mathrm{NO} 3) 21000$ ppm.

Pengambilan Sampel

Pengambilan sampel dilakukan dengan mengambil sampel sebanyak 5 sampai 10 gram daun trembesi di tiap lokasi penelitian dan dimasukkan dalam kantong plastik yang telah di tempelkan label nama. Daun trembesi yang di gunakan sebagai sampel yaitu ibu tangkai daun pangkal pertama dari cabang. Daun yang di ambil adalah yang terletak pada lapisan tajuk paling bawah karena bagian tersebut paling dekat dengan sumber emisi.

Selain itu daun yang diambil terletak pada ruas ke 3-5 yang sudah membentuk daun yang sempurna, dan yang berwarna hijau tua.

Setiap lokasi dilakukan pengambilan 3 sampel daun Trembesi dengan ukuran yang sama. Jadi keseluruhan ada 9 sampel dari tiga lokasi yang berbeda.

Preparasi Analisis 
Preparasi sampel daun trembesi dilapangan dan dibawa ke Laboratorium Baristand untuk di analisis.

Prosedur Kerja

1. Sampel tanaman daun trembesi dibawa ke laboratorium untuk dianalisis

2. Ditimbang sampel sebanyak 5-10 gr dengan teliti dalam cawan porselen

3. Dipanaskan cawan dengan bunsen sampai tidak berasap lagi

4. Dianjurkan pengabuan didalam tanur dengan suhu $550^{\circ} \mathrm{C}$ sampai abu berwarna putih

5. Ditambahkan asam nitrat sebanyak $0,5 \mathrm{ml}$ tetes demi tetes

6. Ditambahkan aquabidest kedalam cawan kemudian diaduk

7. Dipindahkan kedalam labu ukur 50ml, sambil disaring dengan whatman 42

8. Ditepatkan sampai tanda garis dengan menggunakan aquabidest

9. Dibaca absorbansi larutan seri standar dengan menggunakan alat AAS pada panjang gelombang $283,3 \mathrm{~nm}$

10. Dibuat kurva kalibrasi antara konsentrasi logam dan absorbansi

11. Dibaca sampel dan dihitung kandungan logam dalam contoh

Pembuatan Larutan Standar $\mathrm{Pb}$

Larutan induk $\mathrm{Pb} 1000$ ppm di pipet sebanyak $20 \mu \mathrm{l}, 40 \mu \mathrm{l}, 80 \mu \mathrm{l}$ dan $160 \mu \mathrm{l}$ kemudian dimasukkan ke dalam labu ukur $100 \mathrm{ml}$, kemudian diencerkan dengan ultrapurewater hingga tanda garis.

Kemudian homogenkan larutan stadar di ukur absorbansi pada panjang gelombang 283,3 nm dengan menggunakan AAS AA700 metode Flame. Pengukuran Kandungan Timbal $(\mathrm{Pb})$

Penentuan konsentrasi dengan metode Spektrofotometri Serapan Atom (SSA) pada $\mathrm{Pb}$ yang terdapat dalam sampel dengan menggunakan kurva kalibrasi, selanjutnya kandungan $\mathrm{Pb}$ dalam sampel dikonversi menjadi $\mathrm{mg} / \mathrm{kg}$ sampel.

Hasil pengukuran serapan larutan standar dengan panjang gelombang 283,3 $\mathrm{nm}$ dibuat grafik antara serapan dengan konsentrasi larutan standar, dimana nilai absorban pada sumbu y dan konsentrasi pada sumbu $\mathrm{x}$.

Kemudian ditarik masingmasing titik tersebut sehingga diperoleh persamaan garis lurus:

$\mathrm{y}=\mathrm{a}+\mathrm{bx}$

dimana:

$\mathrm{a}=$ Intersep

$\mathrm{b}=$ Slope $\mathrm{x}=$ Konsentrasi $(\mathrm{mg} / \mathrm{L})$

$\mathrm{y}=$ Absorbansi (serapan)

Untuk mencari kadar $\mathrm{Pb}$ dalam sampel digunakan Rumus:

Konsetrasi Logam (mg/kg) :

dimana:

$\mathrm{C}=$ Konsentrasi logam kurva standar

$(\mu \mathrm{g} / \mathrm{ml})$ hasil bacaan alat

$\mathrm{Fp} \quad=$ Faktor pengenceran

$\mathrm{V}=$ Volume sampel $(\mathrm{ml})$

$\mathrm{W}=$ Berat contoh (gr)

\section{Analisis Data}

Analisis data menggunakan uji ANOVA (Analisis of Variance).

Kandungan logam berat timbal $(\mathrm{Pb})$ pada daun trembesi di Taman Kesatuan Bangsa, di Jalan Boulevard dan di Tugu Bobocca, hasilnya akan di bandingkan dengan baku mutu cemaran $\mathrm{Pb}$ di Udara berdasarkan PP No 41 tahun 1999.

Untuk melihat Hubungan kepadatan lalu lintas dengan kandungan $\mathrm{Pb}$ pada daun trembesi di gunakan Uji Korelasi Pearson menggunakan SPSS 21.

\section{HASIL DAN PEMBAHASAN}

\section{Deskripsi Umum Lokasi.}

1. Taman Kesatuan Bangsa ( TKB) merupakan sebuah Taman Kota serbaguna yang lokasinya berada di pusat Kota Manado. Daerah di sekitar Taman Kesatuan Bangsa menjadi Pusat kegiatan Perekonomian Masyarakat. Kondisi lalu lintas di sekitar Taman cukup padat, karena kendaraan melintas di dua arah. Suasana yang cukup panas di Taman Kesatuan Bangsa, namun sedikit tertolong 
dengan adanya pohon peneduh di sekitaran Taman tersebut. Vegetasi yang dominan di sekitar Taman Kesatuan Bangsa, yaitu pohon trembesi dan pohon krey payung. Jarak antar pohon satu dengan pohon lain cukup berdekatan. Tinggi pohon sekitar 8 m.

2. Jalan Boulevard, Kawasan Boulevard merupakan pusat perbelanjaan. Terdapat bangunan-bangunan seperti: mall, hotel dan restoran di sekitar kawasan Boulevard. Kendaraan yang melintas di jalan Boulevard , meliputi kendaraan pribadi, mikrolet. Kecepatan lalu lintas di sekitar jalan tersebut sedang, dan terkadang macet, di karenakan Jalan tersebut satu arah. Vegetasi di kawasan tersebut di dominasi pohon trembesi, jarak pohon satu dengan lain berjauhan. Tinggi pohon trembesi sekitar $3 \mathrm{~m}$ dan sangat dekat dengan jalan raya.

3. Tugu Bobocca, Terletak tepat di perbatasan Kota Manado dan Kabupaten Minahasa. Keunikan Pantai dan kawasan Tugu Bobocca, seperti halnya di kawasan pantai di Malalayang. Terdapat halaman parkir kendaraan yang luas di bagian kiri tugu, yang bisa menampung beberapa kendaraan roda empat. Samping
Tugu juga sudah di alasi lantai paving block, ini merupakan tempat parkir kendaraan roda dua. Di sekitaran tugu terdapat kios-kios penjual pisang goreng dan aneka gorengan lainnya. Kurangnya aktivitas masyarakat dari pagi hingga sore hari serta kurangnya kendaraan yang melintas di jalan tersebut. Jenis kendaraan yang melintas meliputi kendaraan pribadi, serta ada beberapa truck. Di sepanjang jalan terdapat banyak sekali vegetasi pohon pelindung, seperti pohon trembesi, pohon krey payung dan juga pohon ketapang, namun yang paling mendominasi adalah pohon trembesi. Ketinggian pohon ratarata 10 sampai 15 meter, serta jarak pohon sangat berdekatan.

Kandungan Timbal (Pb) pada Daun Trembesi di Kota Manado.

Kandungan timbal $(\mathrm{Pb})$ yang terserap oleh daun trembesi yang berfungsi sebagai pohon pelindung jalan di sekitar kota Manado, masing-masing di Taman Kesatuan Bangsa, Jalan Boulevard dan Tugu Bobocca berbeda untuk setiap lokasi.

Hasil analisis terhadap kandungan partikel logam berat timbal $(\mathrm{Pb})$ yang terserap oleh daun di tiga lokasi tersebut disajikan pada Tabel 4.1.

Tabel 4.1. Kandungan logam berat timbal $(\mathrm{Pb})$ pada daun trembesi (Albizia saman

\begin{tabular}{cccccc}
\multicolumn{5}{c}{ (Jacq.)Merr.) di Kota Manado } \\
Waktu & \multicolumn{2}{c}{ Kandungan timbal (Pb) pada daun } & Satuan & Metode Uji \\
& TKB & JB & TB & & \\
\hline Selasa, 20 April & 0,83 & 0,81 & 0,67 & Ppm & SNI 01-28961998 \\
2021 & & & & & \\
Kamis, 22 April & 0,72 & 0,84 & 0,59 & & \\
2021 & & & & & \\
Sabtu, 24 April 2021 & 0,68 & 0,84 & 0,66 & & \\
Total & 2,23 & 2,49 & 1,92 & & \\
Rata-rata & $\mathbf{0 , 7 4}$ & $\mathbf{0 , 8 3}$ & $\mathbf{0 , 6 4}$ & & \\
\hline
\end{tabular}

Keterangan: TKB (Taman Kesatuan Bangsa), JB (Jalan Boulevard), TB (Tugu Bobocca)

Berdasarkan hasil pengukuran pada Tabel 4.1 kandungan partikel logam berat timbal $(\mathrm{Pb})$ terserap dalam daun menunjukkan bahwa kandungan $\mathrm{Pb}$ yang ada di setiap lokasi hasilnya berbeda.
Daun trembesi yang paling banyak menyerap partikel logam berat timbal $(\mathrm{Pb})$ adalah yang berada di Jalan Boulevard yaitu sebesar $0,83 \mathrm{ppm}$, diikuti di Taman Kesatuan Bangsa yaitu sebesar 0,74 ppm dan di Tugu Bobocca sebesar 0,64 ppm. 
Kandungan $\mathrm{Pb}$ di kota Manado masih dibawah ambang batas baku mutu $\mathrm{Pb}$ di udara berdasarkan PP No 41. Tahun 1999 sebesar 2. Namun jika dibandingkan dengan baku mutu lingkungan untuk parameter $\mathrm{Pb}$ di udara menurut $\mathrm{WHO}$, dengan batas syarat maksimal yang diperbolehkan adalah sebesar 0,5 $\mu \mathrm{g} / \mathrm{Nm} 3$ Kandungan $\mathrm{Pb}$ telah melebihi ambang batas cemaran $\mathrm{Pb}$ di udara menurut standar WHO.

Partikel $\mathrm{Pb}$ yang di serap oleh tanaman akan memberikan efek buruk jika kepekatannya berlebihan. Pengaruh yang di timbulkan antara lain, dengan adanya penurunan pertumbuhan dan produktivitas tanaman serta kematian.

Smith (1981) juga menerangkan gejala akibat pencemaran logam berat adalah terjadinya klorosis dan nekrosis . Logam berat dapat menghambat pertumbuhan sehingga menyebabkan daun akan lebih kecil (Kovacevic et al, 1999).

Logam berat bisa merusak semua permukaan daun kecuali akar, sehingga tanaman masih dapat tumbuh, tanaman yang telah melakukan translokasi konsentrasi dari akar ke daun yang kemudian akan mati dan menggantinya dengan yang baru (Nicholls, 2003).

Hal ini disebabkan karena logam berat yang masuk ke dalam tanaman akan berikatan dengan unsur hara lain dan mengalami immobilisasi ke bagian tanaman tertentu.

Dan tidak dapat diedarkan ke seluruh tanaman karena telah mengalami Bioakumulasi (penimbunan pada organ tertentu) sehingga tanaman masih dapat tumbuh dan unsur hara yang diperlukan tanaman masih mampu untuk mensuplai pertumbuhan tanaman meskipun tercemar logam berat $\mathrm{Pb}$.

Berdasarkan uji ANOVA pada selang kepercayaan $95 \%$ maka didapatkan hasil yang signifikan karena $0,013<0,05$ diketahui bahwa terdapat perbedaan nyata kandungan $\mathrm{Pb}$ pada daun trembesi di masing-masing lokasi pengambilan sampel.

Artinya bahwa secara statistik kandungan $\mathrm{Pb}$ yang terserap pada daun trembesi di masing-masing lokasi penelitian memiliki perbedaan. Perbedaan ini di duga karena banyaknya faktor yang mempengaruhi kandungan $\mathrm{Pb}$ dalam tanaman.

Seperti jangka waktu tanaman kontak dengan $\mathrm{Pb}$, kandungan $\mathrm{Pb}$ dalam tanah, morfologi tanaman, umur tanaman, dan faktor yang mempengaruhi areal seperti banyaknya tanaman penutup.

Kandungan logam berat timbal $(\mathrm{Pb})$ di Jalan Boulevard memiliki kandungan yang paling tinggi, meskipun di Jalan Boulevard ini termasuk dalam kategori kepadatan yang sedang.

Akan tetapi di asumsikan bahwasanya Partikel $\mathrm{Pb}$ dari berbagai tempat terbawa oleh angin sehingga bisa menempel pada daun trembesi yang ada di Jalan Boulevard.

Hal ini sesuai dengan pendapat ( Dahlan, 2003 ) bahwasanya logam berat yang berbentuk partikel bebas sebagian akan menempel pada tumbuhan salah satunya pada bagian daun, partikel tersebut akan terserap ke dalam ruang stomata daun.

Pohon trembesi di Jalan Boulevard memiliki tinggi pohon yang paling rendah di banding dengan lokasi lain. Hal ini diduga menyebabkan di Jalan Boulevard mampu menyerap timbal lebih banyak karena posisi daun lebih dekat dengan sumber pencemar.

Semakin tinggi tingkat pencemaran akan menyebabkan semakin tinggi $\mathrm{Pb}$ dalam tanaman. Jumlah $\mathrm{Pb}$ di udara dipengaruhi oleh volume atau kepadatan lalu lintas, jarak dari jalan raya dan daerah industri, percepatan mesin dan arah angin (Siregar, 2005).

Pada saat pengambilan daun di Jalan Boulevard daun di lokasi ini berwarna agak kehitaman diketahui bahwa gas 
pencemar udara yang terpapar dengan konsentrasi yang cukup tinggi menyebabkan daun tersebut berwarna agak kehitaman.

Kandungan logam berat timbal $(\mathrm{Pb})$ di Taman Kesatuan Bangsa memiliki kandungan yang sedang atau lebih rendah di bandingkan dengan Jalan Boulevard. Meski jumlah kendaraan di Taman Kesatuan Bangsa lebih banyak di banding lokasi lain, hanya saja pada lokasi tersebut pohon peneduh lebih banyak sehingga kandungan $\mathrm{Pb}$ di udara tersebar ke beberapa pohon pelindung lainnya. Seperti yang di kemukakan Siregar (2005) bahwa banyakya tanaman penutup serta jenis tanaman di sekeliling tanaman tersebut merupakan faktor yang mempengaruhi kandungan $\mathrm{Pb}$ tanaman. Kandungan logam berat timbal $(\mathrm{Pb})$ terendah terdapat di Tugu Boboca. Rendahnya kandungan timbal $(\mathrm{Pb})$ ini di duga karena Jumlah kendaraan bermotor yang melintas di lokasi tersebut lebih sedikit di banding lokasi lainnya.
Tingginya tingkat kepadatan lalu lintas mengurangi ruang gerak kendaraan, kondisi ini berpotensi menyebabkan kemacetan yang berdampak secara langsung terhadap peningkatan pencemaran udara (Muldiyanto et al., 2007).

Perbedaan kandungan $\mathrm{Pb}$ pada setiap lokasi juga terjadi karena jarak sampel dengan sumber pencemar. Semakin dekat jarak sampel dengan sumber pencemar, maka sampel akan tercemar lebih besar.

4.1 Hubungan Kepadatan Lalu Lintas dengan Kandungan Timbal $(\mathrm{Pb})$ pada Daun Trembesi (Albizia saman (Jacq.) Merr.) di Taman Kesatuan Bangsa, Jalan Boulevard dan Tugu Boboca

Perhitungan jumlah kendaraan di lakukan pada pukul 09.00-10.00 pagi dan pukul 15.00-16.00 sore pada tiga lokasi dengan $\quad 3 \quad$ kali pengulangan.

Hasil perhitungan jumlah kendaraan pada masing-masing lokasi pengambilan sampel pada Tabel 4.3

Tabel 4.3.Jumlah Kendaraan Bermotor di Taman Kesatuan Bangsa, Jalan Boulevard dan Tugu Boboca

\begin{tabular}{lcc}
\hline Lokasi & Rata-rata Kendaraan bermotor & $\begin{array}{c}\text { Kandungan } \\
\text { didaun (Ppm) }\end{array}$ \\
\hline Taman Kesatuan Bangsa & 30.667 & 0,74 \\
Jalan Boulevard & 22.895 & 0,83 \\
Tugu Bobocca & 11.829 & 0,64 \\
\hline
\end{tabular}

Berdasarkan Tabel 4.3 mengenai korelasi antara jumlah kendaraan bermotor dengan kandungan $\mathrm{Pb}$ menunjukkan bahwa lokasi di Taman Kesatuan Bangsa menghasilkan rataan kendaraan bermotor adalah 30.667 dengan kandungan $\mathrm{Pb}$ di daun trambesi adalah $0.74 \mathrm{ppm}$.

Bermotor dengan kandungan $\mathrm{Pb}$ pada lokasi Jalan Boulevard dengan rataan jumlah kendaraan bermotor dengan nilai rataan 22.895 dan kandungan $\mathrm{Pb}$ 0,83 ppm. Untuk lokasi Tugu Bobocca menghasilkan rataan 11.829 untuk jumlah kendaraan bermotor dengan nilai kandungan $\mathrm{Pb}$ adalah 0,64 ppm.

Hasil perhitungan menunjukkan bahwa adanya hubungan antara jumlah kendaraan bermotor dengan kandungan $\mathrm{Pb}$ pada daun trembesi, akan tetapi hubungan yang terjadi antara jumlah kendaraan bermotor dengan kandungan $\mathrm{Pb}$ ini sedang.

Samat (2002), menyatakan bahwa kadar $\mathrm{Pb}$ pada tanaman di pengaruhi oleh jumlah kendaraan bermotor. Jumlah kendaraan yang melewati tiap-tiap titik pengambilan sampel di Kota Manado tidak terlalu berpengaruh kuat dengan tingginya 
kandungan $\mathrm{Pb}$, dikarenakan penelitian ini

dilakukan pada hari yang berbeda.

Tabel 4.4 Analisis Korelasi jumlah kendaraan bermotor dengan Kandungan $\mathrm{Pb}$ pada daun Trembesi

\begin{tabular}{llll}
\hline & & $\begin{array}{l}\text { Jumlah } \\
\text { Kendaraan } \\
\text { Motor }\end{array}$ & $\begin{array}{l}\text { kandungan } \\
\mathrm{pb}\end{array}$ \\
\hline $\begin{array}{l}\text { jumlah kendaraan } \\
\text { motor }\end{array}$ & $\begin{array}{l}\text { Pearson } \\
\text { Correlation } \\
\text { Sig. (2-tailed) }\end{array}$ & 1 & 0,530 \\
kandungan pb & N & 9 & 0,142 \\
& Pearson & 0,530 & 9 \\
& Correlation & & 1 \\
& Sig. (2-tailed) & 0,142 & \\
& N & 9 & 9 \\
\hline
\end{tabular}

Hal ini menyebabkan jumlah kendaraan bermotor tidak berkorelasi kuat dengan tingginya kandungan logam berat timbal $(\mathrm{Pb})$ pada daun trembesi.

Kandungan logam berat timbal $(\mathrm{Pb})$ di Jalan Boulevard memiliki kandungan yang paling tinggi, meskipun di Jalan Boulevard ini termasuk dalam kategori kepadatan yang sedang, akan tetapi di asumsikan bahwasanya.

Partikel $\mathrm{Pb}$ dari berbagai tempat terbawa oleh angin sehingga bisa menempel pada daun trembesi yang ada di Jalan Boulevard, hal ini sesuai dengan pendapat ( Dahlan, 2003 ) bahwasanya logam berat yang berbentuk partikel bebas sebagian akan menempel pada tumbuhan salah satunya pada bagian daun, partikel tersebut akan terserap ke dalam ruang stomata daun.

Tingginya kandungan timbal $(\mathrm{Pb})$ pada daun trembesi di Jalan Boulevard juga dikarenakan letaknya yang lebih dekat dengan sumber emisi dan jarak pohon satu dengan pohon lain berjauhan.

Tinggi pohon dan posisi daun berpengaruh terhadap kemampuannya menyerap timbal (Istiaroh et al.,2014). Tinggi pohon yang lebih rendah mampu menyerap timbal lebih banyak.

Pohon trembesi di Jalan Boulevard memiliki tinggi pohon yang paling rendah di banding dengan lokasi lain. Hal ini diduga menyebabkan di Jalan Boulevard mampu menyerap timbal lebih banyak karena posisi daun lebih dekat dengan sumber pencemar.

Hal ini juga didukung oleh penelitian Freer-Smith et al. (1997) yang menjelaskan bahwa debu banyak terakumulasi pada daun tanaman yang dekat dengan jalan mobil.

Semakin tinggi tingkat pencemaran akan menyebabkan semakin tinggi $\mathrm{Pb}$ dalam tanaman. Jumlah $\mathrm{Pb}$ di udara dipengaruhi oleh volume atau kepadatan lalu lintas, jarak dari jalan raya dan daerah industri, dan arah angin (Siregar, 2005).

Kandungan logam berat timbal $(\mathrm{Pb})$ terendah terdapat di Tugu Boboca.. Koefisien korelasi jumlah kendaraan bermotor dengan nilai rataan 11.829 dan nilai kandungan $\mathrm{Pb} 0,64$ di lokasi Tugu Bobocca.

Diduga pada lokasi tersebut dipengaruhi oleh kurangnya aktifitas masyarakat pada pagi dan sore hingga malam hari dengan menggunakan kendaraan bermotor. Serta jalur tersebut bukan merupakan jalur lintasan padat yang menyebabkan akumulasi $\mathrm{Pb}$, serta diduga bahwa angin sangat mempengaruhi kumulasi $\mathrm{Pb}$. Tinggi rendahnya kandungan $\mathrm{Pb}$ pada setiap lokasi tidak hanya di pengaruhi oleh 
jumlah kendaraan bermotor, tetapi ada faktor lain yang mempengaruhi yaitu jarak pohon trembesi dengan sumber pencemar.

Semakin dekat jarak pohon trembesi dengan sumber pencemar, maka akan tercemar lebih besar. Sebaliknya, semakin jauh jarak pohon dari sumber pencemar, semakin rendah konsentrasi cemaran $\mathrm{Pb}$ yang terukur (Sanra et all., 2015).

Tingginya kandungan timbal pada daun trembesi, di akibatkan karena tingginya tingkat pencemaran. Jumlah $\mathrm{Pb}$ di udara dipengaruhi oleh volume atau kepadatan lalu lintas, jarak dari jalan raya dan daerah industri, dan arah angin (Siregar, 2005).

\section{KESIMPULAN}

Kandungan logam berat timbal $(\mathrm{Pb})$ yang ada di Kota Manado, dibeberapa tempat seperti di Taman Kesatuan Bangsa, Jalan Boulevard dan sekitar Tugu Bobocca berkisar antara 0,59-0,84 Ppm. Berdasarkan baku mutu $\mathrm{Pb}$ di udara menurut PP No. 41 Tahun 1999 sebesar 2 $\mu \mathrm{g} / \mathrm{Nm} 3$ Kandungan $\mathrm{Pb}$ di kota Manado masih dibawah ambang batas baku mutu $\mathrm{Pb}$ di udara. Namun jika dibandingkan dengan baku mutu lingkungan untuk parameter $\mathrm{Pb}$ di udara menurut WHO, dengan batas syarat maksimal yang diperbolehkan adalah sebesar $0,5 \mu \mathrm{g} / \mathrm{Nm} 3$ Kandungan $\mathrm{Pb}$ telah melebihi ambang batas cemaran $\mathrm{Pb}$ di udara menurut standar WHO.

Hubungan kepadatan lalu lintas dengan kandungan timbal $(\mathrm{Pb})$ pada daun trembesi menunjukkan bahwa adanya hubungan antara jumlah kendaraan bermotor dengan kandungan $\mathrm{Pb}$ pada daun trembesi , akan tetapi hubungan yang terjadi antara jumlah kendaraan bermotor dengan kandungan $\mathrm{Pb}$ ini lemah. Tinggi rendahnya kandungan $\mathrm{Pb}$ pada daun tidak hanya di pengaruhi oleh banyaknya jumlah kendaraan yang melintas dijalan, tetapi ada faktor lain yaitu arah dan kecepatan angin, serta jarak pohon dengan sumber pencemar.

\section{SARAN}

Perlu diupayakan penanaman pohon trembesi atau jenis tanaman lainnya sebagai pohon peneduh pada ruas jalan di Kota Manado, karena daun tanaman ini memiliki daya serap terhadap logam berat timbal $(\mathrm{Pb})$ agar dapat membantu mengurangi pencemaran udara.

\section{DAFTAR PUSTAKA}

Badan Pusat Statistik Kota Manado. 2019. Kota Manado dalam Angka 2018. Manado. BPS.

Darmono, 1995, Logam Dalam Sistem Biologi Makhluk Hidup, UI Press : Jakarta

Ferdiaz, S. 1992. Polusi Air dan Udara. Konisius. Yogyakarta.

Freer-Smith PH, Holloway S, Goodman A. 1997. The uptake of particulates by an urban woodland: site description and particulate composition. Environ Pollut 95: 27 35.

Gunarno. 2014. Pengaruh Pecemaran Udara Terhadap Luas Daun dan Jumah Stomata Daun Rhoeo Discolor. Widyaiswara Muda BDK Medan.

Hasbiah, A. W., \& Musaddad, F. 2016. Studi Identifikasi Pencemaran Udara oleh Timbal $(\mathrm{Pb})$ pada Area Parkir (Studi Kasus Kampus Universitas Pasundan Bandung). Jurnal Infomatek, 18(1), 49-56.

Karimuddin, N.K. 2016. Pengaruh Pemberian Pupuk Hijau Cair Kihujan (Samanea Saman) dan Azolla (Azolla Pinnata) Terhadap

Kandungan Selulosa dan Hemiselulosa Rumput Gajah (Pennisetum Purpureum). Skipsi. Makassar

Kovacevic G., Kastori R., \& Merkulov L. 1999. Dry matter and leaf structure in young wheat plants as affected by cadmium, lead, and 
nickel. Biologia Plantarum, 42, 119 23.

Lestari, P. 2006. Faktor-faktor yang berpengaruh terhadap kadar timbal dalam darah anak-anak Sekolah Dasar di Kota Bandung. Journal Indonesian Lead Information Center, 7(2), 35-41.

Martuti, N. K. T. 2013. Peranan tanaman terhadap pencemaran udara di Jalan Protokol Kota Semarang. Biosaintifika: Journal of Biology \& Biology Education, 5(1).

Muldiyanto, A., Mudjiastuti, H., \& Mukti, W. 2007. Kualitas Udara Akibat Kegiatan Transportasi di Kota Semarang. Prosiding Seminar Nasional. B-14: 1-6.

Ngabekti, S. 2004. Manfaat Tanaman Peneduh Jalan dalam Mempengaruhi Lingkungan Mikro dan Kualitas Udara di Kota Semarang. Jurnal Mipa, 27(1), 56-64.

Nicholls, Ann, M., \& Mal, T. 2003. Effects of lead and copper exposure on growth of an invasive weed, Lythrum Salicaria L. (Purple Loosestrife). Journal of Science, 103(5), 129 - 133.

Ningrum, I. S., Yoza, D., \& Arlita, T. 2016. Kandungan Timbal $(\mathrm{Pb})$ pada Tanaman Peneduh di Jalan Tuanku Tambusai Kota Pekanbaru (Doctoral dissertation, Riau University).

Palar, H. 2004. Pencemaran dan Toksikologi Logam Berat. PT. Rineka Cipta Jakarta.

Peraturan Pemerintah Republik Indonesia Nomor 41, 1999. Tentang Standar Kualitas Udara Ambien. Jakarta.

Ruslinda, Y., Gunawan, H., Goembira, F., \& Wulandari, S. 2016. Pengaruh Jumlah Kendaraan Berbahan Bakar Bensin terhadap Konsentrasi Timbal $(\mathrm{Pb})$ di Udara
Ambien Jalan Raya Kota Padang. In Seminar Nasional Sains dan

Teknologi Lingkungan II eISSN (Vol. 2541, p. 3880).

Santoso, S. N. $2012 . \quad$ Penggunaan Tumbuhan Sebagai Pereduksi Pencemaran Udara Plant Application As Reducer Air Pollution. Jurnal FTSP-ITS Jurusan Teknik Lingkungan.

Siregar, B. M. E. 2005. Pencemaran Udara, Respon Tanaman dan Pengaruhnya terhadap Manusia. Jurnal Pertanian. Universitas Sumatra Utara. Medan.

Suhaemi, Maryono, \& Sugiarti. 2014. Analisis Kandungan Timbal (Pb) pada Daun Trembesi ( Samanea saman (Jacq .) Merr ) di Jalan Perintis Kemerdekaan Makassar dengan Metode Spektrofotometri Serapan Atom ( SSA ). Jurnal Chemica, 15(2): 85-94.

Suksmeri. 2003. Faktor - Faktor yang Mempengaruhi Kadar

Karbonmonoksida di Beberapa Ruas Jalan di Kota Padang. Tesis.

Suryowinoto. 1997. Flora Eksotika Tanaman Peneduh. Kanisius. Yogyakarta.

Wardhana, A. 2004. Penentuan Luasan Hutan Kota Berdasarkan Kemampuan dalam Menyerap dan Menjerap Timbal di Kota Bogor. Skripsi. Institut Pertanian Bogor. Bogor.

Wardhana, A.W. 2001. Dampak Pencemaran Lingkungan. Penerbit Andi. Yogyakarta.

Widagdo,Setyo.2005.Tanaman Elemen Lanskap Sebagai Biofilter Untuk Mereduksi Polusi Timbal $(\mathrm{Pb})$ di Udara. Sekolah Pasca Sarjana IPB Bogor. 
Widowati, W., Sastiono, A., \& Jusuf, R. 2008. Efek Toksik Logam. Penerbit Andi. Yogyakarta.

Witchayo, E. 2014. Kadar Timbal dalam Darah dan Kebijakan Pencegahan pada Pengemudi LYN TV di Kota
Surabaya. Jurnal IKESMAS, Volume 10.

Zahro, M. 2006. Potensi Pohon Jalan untuk Menyerap Logam Berat Timbal $(\mathrm{Pb})$ di Daerah Padat Lalu Lintas Kota Malang. Skripsi. UIN Malang. Malang. 